\title{
SIDE EFFECTS OF INJECTABLE AND ORAL CONTRACEPTIVE AND UNINTENDED PREGNANCY AMONG REPRODUCTIVE WOMEN IN INDONESIA
}

\author{
Maria Gayatri $^{1}$, Dian Kristiani Irawaty ${ }^{2}$ \\ 1,2National Population and Family Planning Board East Jakarta, Indonesia \\ Corresponding Author: Maria Gayatri \\ Email: maria.gayatri.bkkbn@gmail.com
}

\begin{abstract}
Using contraception is essential for protecting women from the risk of unintended pregnancy. However, contraceptive discontinuation, caused by side effects of contraceptives or health problems, is still high. This study aimed to assess the impact of injectable and pill contraception discontinuation due to side effects or health problems on unintended pregnancy among women aged 15-49 years in Indonesia. This study is based on the 2017 Indonesia Demographic and Health Survey. As many as 1,613 women who discontinued their oral contraceptives and 5,022 women who discontinued their injectables were followed retrospectively. Pregnancy rates were tested for differences between categories using survival analysis. It was found that one year after stopping contraceptives due to side effects, almost $16-17 \%$ of oral/injectable contraceptive users were already pregnant. The pregnancy rate was higher among women aged less than 25 years. Unplanned pregnancy occurred more frequently among women who were not working than women who were working. Counseling services need to be strengthened by improving provider knowledge and skills to give comprehensive information including contraceptives' side effects.
\end{abstract}

Keywords: hormonal contraceptives, side effects, unintended pregnancy, survival analysis

\begin{abstract}
ABSTRAK
Penggunaan kontrasepsi sangat penting untuk melindungi wanita dari kehamilan yang tidak diinginkan. Namun, tingkat putus pakai kontrasepsi karena efek samping atau masalah kesehatan masih tinggi. Penelitian ini bertujuan untuk mengetahui dampak putus pakai kontrasepsi suntik dan pil karena efek samping atau masalah kesehatan terhadap kehamilan yang tidak diinginkan. Data dikutip dari Survei Demografi dan Kesehatan Indonesia tahun 2017. Terdapat 1.613 episode wanita yang putus pakai pil KB dan 5.022 episode wanita yang putus pakai suntikan yang diikuti secara retrospektif. Tingkat kehamilan pasca putus pakai kontrasepsi akan diuji perbedaan antar kategorinya dengan menggunakan analisis kesintasan. Hasil menunjukkan bahwa satu tahun pasca putus pakai kontrasepsi karena efek samping atau masalah kesehatan, sekitar 16-17\% akseptor pil/suntik KB hamil.Tingkat kehamilan terjadi lebih tinggi pada wanita berumur kurang dari 25 tahun. Risiko terjadinya kehamilan yang tidak direncanakan lebih besar pada wanita yang tidak bekerja dibandingkan pada wanita yang bekerja. Oleh karena itu, perlu penguatan layanan konseling termasuk kompetensi tenaga konselor dan penyuluh dalam memberikan informasi yang lengkap dan komprehesif termasuk terkait efek samping kontrasepsi.
\end{abstract}

Kata kunci: kontrasepsi hormonal, efek samping, kehamilan yang tidak diinginkan, analisis kesintasan.

\section{INTRODUCTION}

In developing countries, unintended pregnancy remains a public health issue. Unintended pregnancy is associated with severe and adverse health consequences. This includes unsafe abortions with a high risk of maternal morbidity, fetal and infant morbidity and mortality, inadequate prenatal care for mothers, inadequate childhood vaccination, and stunting (Curtis et al., 2011; Hussain and Finer, 2013; A. Singh et al., 2015). An estimated 22 million unsafe abortions occur per year, of which about percent occur in developing countries (World Health Organization, 2012). Unintended pregnancy occurred when the time of conception was either mistimed (earlier than desired) or unwanted (women desire no more births) (A. Singh et al., 2015; S. Singh et al., 2014). On the opposite side, intended pregnancy is a pregnancy that occurs at or later than the desired "right time" (A. Singh et al., 2015).

In Indonesia, many women who become pregnant unintentionally choose to end 
their pregnancy by abortion (Sedgh and Ball, 2008). Abortion is illegal in Indonesia except in the case of a pregnancy that arises from rape or to save the life of the mother. Nearly half of all Indonesian women seeking abortion resort to unskilled birth attendants, traditional healers, or masseurs to terminate their pregnancy (Sedgh and Ball, 2008). Unsafe abortions are a threat to women's health. A recent study showed that there were 42.5 abortions per 1,000 reproductive-aged women (15-49 years) in Java (Giorgio et al., 2020). The abortion methods used in Java were surgical, medication, јати (traditional Javanese herbal medicine), and others.

Unmet needs for contraceptives remained high among women amid decades of increases in contraceptive use in Indonesia. Women with unmet needs are those who wish to delay or limit their births, but do not use any form of contraceptives. Unmet needs are also faced by women who discontinue their contraception with the reason of wanting to be pregnant. Unintended pregnancies can occur when contraceptives are used (referred to contraceptive failures) or when women who do not want to have birth are not using a contraceptive method (unmet need). This can happen due to early sexual initiation, partner's desire for a child, and less autonomy (Habte $e t$ $a l ., 2013)$. Using contraception is essential to protect women from unintended pregnancies (Habte et al., 2013). However, many women decided to stop their contraception. The common reasons for contraceptive discontinuation were reported failure, desire to become pregnant, reasons caused by the contraceptives such as side effects, health problems, medical advice, no longer needing contraceptives due to abstinence or divorce (Ali et al., 2012). The review of studies from 36 developing countries showed that around onethird of recent unplanned pregnancies were attributed to the discontinuation of contraceptive methods (Jain and Winfrey, 2017).

Injectables and oral contraceptives are the most preferred method in Indonesia, but a significant proportion of injectable and oral contraceptive users are facing the risk of contraceptive method failures, side effects, and health problems. Injectables and oral contraceptives are effective yet reversible hormonal contraception. The effectiveness of injectables and oral contraceptives in protecting to the risk of pregnancy depends on how users comply with the contraceptive schedule since the unintended pregnancy might occur in women who missed their injection schedule (World Health Organization and John Hopkins Bloomberg School of Public Health/Center for Communication Programs, 2018). Oral contraceptives require daily compliance and need to be used in the correct ways. Annual failure rates with typical use of oral contraceptives are at 7 pregnancies per 100 women using oral contraceptives, while failure rates for injectables are smaller, about 4 pregnancies per 100 women (World Health Organization and John Hopkins Bloomberg School of Public Health/Center for Communication Programs, 2018).

Ideally, if a woman experienced a side effect or health concern of contraception but she did not want to be pregnant, she could switch contraception methods to still ensure protection from pregnancy. However, some women choose to not use any methods after experiencing side effects or health concerns. There is little information about unplanned pregnancies after contraceptive side effects or health concerns. This study tried to fill these gaps by focusing on injectables and oral contraception. For reasons other than the urge to become pregnant, this research is important for understanding the unintended effect of short-acting hormonal contraceptive discontinuation on pregnancy.

\section{METHODS}

Data were extracted from the 2017 Indonesia Demographic and Health Survey (IDHS). There were four questionnaires used in the IDHS: household questionnaire, women's questionnaire (for those aged 15-49 years), married man's questionnaire (for those aged 1554 years), and never married man's questionnaire (for those aged 15-24 years). The analyses utilized a women's questionnaire focusing on the contraceptive history calendar data.

The IDHS is a cross-sectional and population-based survey with national coverage. The survey is conducted every five years in all provinces in Indonesia. The IDHS was conducted by Statistics Indonesia, the National Population and Family Planning Board, and Indonesian Ministry of Health with technical 
assistance from the ICF (National Population and Family Planning Board et al., 2018). IDHS used multi-stage cluster sampling methods. In the first stage of sampling, the primary sampling unit (PSU) was determined by probability proportional to size. In the next stage, the enumeration areas (EA) were chosen randomly from the selected PSUs followed by a systematic selection of households.

The calendar data provided a monthby-month history of key-related events in women of reproductive age's life for five years before the date of the survey interview (USAID, 2018). The calendar data identified the timing of pregnancy following contraceptive discontinuation. The calendar data consisted of birth, pregnancies, terminations, contraceptive use, the reason for discontinuation of contraceptive use, marital history, and source of contraceptive methods (USAID, 2018).

In this study, the calendar data were extracted based on each episode of contraceptive history for each woman. Furthermore, the extracted calendar data were merged with the dataset for women after understanding the details of data coding.

The outcome variable was the time (monthly) between oral contraceptives and injectables stopping because women experienced side effects or health concerns, and the event of unplanned pregnancy. The time was available through calendar data extraction. This research was limited only to oral contraceptives and injectables because both methods were the most favorable reversible contraceptive methods in Indonesia (National Population and Family Planning Board et al., 2018).

The predictors in this research were women in specified age groups $(15-24,25-34$, and 35-49), parity (none, 1-2, 3 or more), duration of the last contraceptive used $(6$ months, 6-12 months, 13-24 months, and >24 months), women's education attainment (low, middle, and high), women's occupation (not working and working), and place of residence (urban and rural). The educational attainment was categorized as "low" for primary or less education, "middle" for secondary education attainment, and "high" for higher education attainment.

Descriptive statistics were presented for categorical and numeric variables including women's characteristics and (unplanned) pregnancy rates following discontinuation of contraceptive use. Data were analyzed using survival analysis. A life table was used to analyze the probability of pregnancy after oral contraceptive and injectable discontinuation due to side effects or health concerns. KaplanMeier survival function statistics were performed to estimate the pregnancy rates of women who discontinued contraceptives due to side effects/health problems. The log-rank statistical analysis was used to assess the differences in time to pregnancy between categories of related factors.

All analyses in the study were weighted for generalized purposes. Sampling weights were applied for adjustment of the unequal probability of sampling selection of cases between areas. The analysis used the Stata IC 15.1 command do file to estimate cumulative pregnancy rates following discontinuation of contraceptive use. STATA version 15.1 was used for analysis.

Data in this study did not include any personal identity when downloading from the Demographic and Health Survey (DHS) website; therefore, ethical approval was not needed. However, authors had the permission from the DHS to utilize the dataset.

\section{RESULTS}

\section{Sample Characteristics}

The respondents of the study were currently married women of reproductive age (15-49 years). Of these women there were 6,635 episodes of injectables and oral contraceptive discontinuation during five years preceding the survey because of various reasons: pregnant while using contraceptives, desire to get pregnant, side effects, health concerns, wanted more effective method, husband disapproved, lack of access or availability, inconvenient when using the contraceptives, infrequent sex, cost, and divorce. Intended pregnancy is defined as pregnancy among women who discontinued using contraceptives because they desired to get pregnant. Unintended pregnancy on the other hand is defined as pregnancy among women who discontinued using contraceptives because of other reasons than the need to become pregnant. This study focused on women who discontinued using short-acting hormonal contraceptives (injectables and oral contraceptives) for the reason of side effects and/or health concerns. 
Table 1. Distribution of reasons for discontinuation of injectables and oral contraceptives during five years preceding the survey (IDHS 2017)

\begin{tabular}{lccc}
\hline \multicolumn{1}{c}{ Reason for Discontinuation } & Injectables & Oral Contraceptives & Total \\
\hline Contraceptive failure & $342(2.7 \%)$ & $569(10.2 \%)$ & $911(5.1 \%)$ \\
Desire to get pregnant & $3,887(31.2 \%)$ & $1,641(29.3 \%)$ & $5,529(30.6 \%)$ \\
Side effects/health concerns & $5,022(40.3 \%)$ & $1,613(28.8 \%)$ & $6,635(36.7 \%)$ \\
Other reasons & $3,212(25.8 \%)$ & $1,777(31.7 \%)$ & $4,989(27.6 \%)$ \\
\hline Total & $12,463(100 \%)$ & $5,600(100 \%)$ & $18,063(100 \%)$ \\
\hline
\end{tabular}

Source: Computed by the authors from IDHS 2017 data

Table 2. Contraceptive use discontinuation due to side effects/health concerns by socio-demographic characteristics

\begin{tabular}{|c|c|c|c|c|}
\hline \multirow{2}{*}{$\begin{array}{l}\text { Socio-Demographic } \\
\text { Characteristics }\end{array}$} & \multicolumn{2}{|c|}{$\begin{array}{l}\text { Discontinuation Due to Side Effects } \\
\text { and/or Health Concerns }(\%)\end{array}$} & \multirow{2}{*}{$\begin{array}{c}\text { Log-rank } \\
\chi^{2}\end{array}$} & \multirow{2}{*}{ p-value } \\
\hline & $\begin{array}{c}\text { Injectables } \\
(\mathrm{n}=\mathbf{5 , 0 2 2} \mathbf{~ e p s})\end{array}$ & $\begin{array}{l}\text { Oral Contraceptives } \\
\quad(\mathrm{n}=1,613 \mathrm{eps})\end{array}$ & & \\
\hline \multicolumn{5}{|l|}{ Age group } \\
\hline $15-24$ & 9.8 & 7.4 & 142.9 & 0.000 \\
\hline $25-34$ & 40.1 & 38.0 & & \\
\hline $35-49$ & 50.1 & 54.6 & & \\
\hline \multicolumn{5}{|l|}{ Parity } \\
\hline None & 0.5 & 0.7 & 131.12 & 0.000 \\
\hline $1-2$ & 65.6 & 63.3 & & \\
\hline 3 or more & 33.9 & 36.0 & & \\
\hline \multicolumn{5}{|l|}{ Duration of Use } \\
\hline$<6$ months & 24.7 & 49.0 & 248.02 & 0.000 \\
\hline 6-12 months & 12.0 & 12.9 & & \\
\hline 13-24 months & 18.8 & 15.6 & & \\
\hline$>24$ months & 44.5 & 22.5 & & \\
\hline \multicolumn{5}{|l|}{ Educational Attainment } \\
\hline Low & 32 & 26.6 & 4.89 & 0.10 \\
\hline Middle & 57.2 & 59.7 & & \\
\hline High & 10.8 & 13.7 & & \\
\hline \multicolumn{5}{|l|}{ Occupation } \\
\hline Not working & 37.8 & 37.3 & 419.65 & 0.000 \\
\hline Working & 62.2 & 62.7 & & \\
\hline \multicolumn{5}{|l|}{ Place of Residence } \\
\hline Rural & 49.3 & 45.3 & 2.62 & 0.10 \\
\hline Urban & 50.7 & 54.7 & & \\
\hline
\end{tabular}

Source: Computed by the authors from IDHS 2017 data

Table 1 shows the distribution of reasons for injectable and oral contraceptive discontinuations during the five years preceding the survey. Reasons of side effects and/or health concerns caused about $37 \%$ of injectables and oral contraceptive discontinuation.

The proportion of contraceptive discontinuation because of side effects and/ or health concerns was higher among injectable users than among oral contraceptive users. The proportion of contraceptive discontinuation because of contraceptive failures was lower among injectables users than oral contraceptive users.

The ages of injectable users were slightly younger than oral contraceptive users. The mean ages of injectables and oral contraceptive users were 34.5 and 35.5 respectively. Table 2 shows almost half of injectables and oral contraceptives discontinuation because of side effects and/or health concerns occurred among women aged 35-49 years, an age group with a high risk of becoming pregnant. Based on the number of 
children-ever-born (parity), more than $60 \%$ of episodes of discontinuation due to side effects and/or health concerns occurred in women who had one or two children (Table 2). Among nulliparous contraceptive users, only a very small proportion discontinued using contraceptives for the reason of side effects and/or health reasons.

Contraceptive use duration before discontinuation due to side effects and/or health concerns was longer among injectables than among oral contraceptive users. Contraceptive use for more than 2 years before discontinuation occurred in $45 \%$ of injectable users and $23 \%$ of oral contraceptive users. Meanwhile, the use of contraceptives for less than 6 months before discontinuation occurred in $25 \%$ of injectable users and $49 \%$ of oral contraceptive users. Regarding occupation background, the proportion of not working among women who discontinued using due to side effects and/or health concerns contraceptives was lower than women who were working. There was not much difference in terms of educational and residential site backgrounds between injectable users and oral contraceptive users who discontinued using contraceptives due to side effects and health concerns.

\section{Pregnancy Following Injectable and Pill Discontinuation}

Women who stopped their contraceptives due to side effects/health concerns were at risk of unintended pregnancy if they did not decide to switch their contraceptive methods. Switching contraceptives to more suitable methods can prevent unintended pregnancy and reduce the risk of maternal deaths and other negative reproductive health outcomes due to unsafe abortions.

Women of reproductive age within the post-injectable and oral contraceptive discontinuation face a high risk of unintended pregnancy. Women who did not want to become pregnant were at risk of unintended pregnancy due to the absence of contraceptive use. Figure 1 shows pregnancy rates of women of reproductive age after oral contraceptive discontinuation due to side effects/health concerns were relatively high: around $13 \%$ within six months, $17 \%$ within 12 months, and about $35 \%$ within 24 months post-oral contraceptive discontinuation. The pregnancy rates after injectable discontinuation were $8 \%$ within 6 months, $16 \%$ within 12 months, and about $33 \%$ within 24 months.

The unintended pregnancy rates in two years were slightly higher among previous oral contraceptive users than among injectable users, higher among younger women, higher among women with three or more children, higher among shorter-use duration before discontinuation, and higher among not-working women. Educational and residential site backgrounds seem unrelated to unintended pregnancy. Of the demographic background characteristics, women's age was most related to the unintended pregnancy rate. Postcontraceptive discontinuation unintended pregnancy rates in one year among women aged 15-24 years, 25-34 years, and 35-49 years were $20 \%, 20.1 \%$, and $13 \%$, respectively.

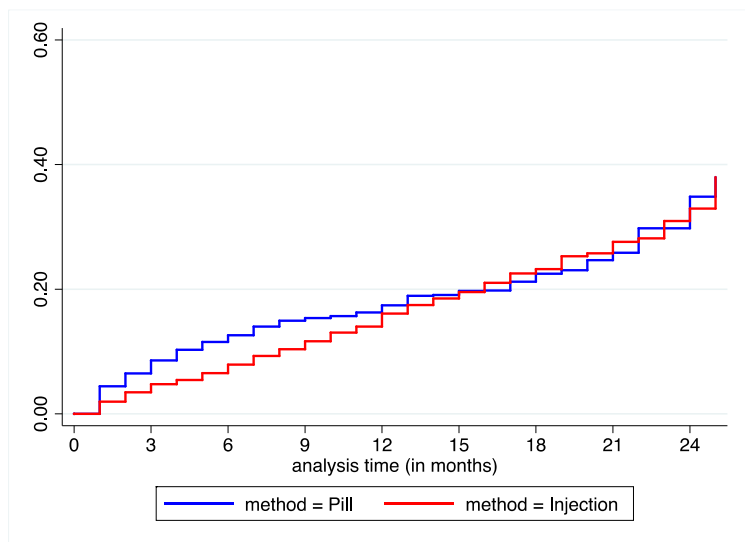

Figure 1. Cumulative pregnancy rates following contraceptive discontinuation due to side effects/health concerns

Figure 1 shows net cumulative pregnancy rates at a set of periods after discontinuation of injectables and oral contraceptives due to side effects/health concerns. The time needed to become pregnant following discontinuation of contraceptives due to side effects/health concerns was shorter among oral contraceptive users than among injectable users.

\section{DISCUSSION}

A total of 1,613 episodes and 5,022 episodes were studied containing information on the contraceptive use history of women after discontinuation of pills and injectables due to side effects/health concerns, 
respectively. Of the oral ex-users, $13 \%$ reported being pregnant within 6 months and 17\% reported being pregnant within one year post-oral contraceptive discontinuation for the reason of side effects. Moreover, in the first semester, $8 \%$ of ex-injectable users were pregnant; this number increased twofold to $16 \%$ within one year following injectable discontinuation due to side effects.

Injectable and oral contraceptives are contraceptives with high efficacy for spacing and limiting under the proper and consistent use. Under the perfect use, it is estimated that the proportion of becoming pregnant during a year of injectables and oral contraceptives should be very low at about $0.2 \%-0.3 \%$ (World Health Organization, 2016). However, contraceptive failures still occur among a small proportion of contraceptive users. This study found contraceptive failure to be a factor for the discontinuation of contraceptive use for oral contraceptives more often than for injectable users. Other studies with similar results cited this may be due to injectables having lower failure rates than oral contraceptives (Polis et al., 2016; World Health Organization and John Hopkins Bloomberg School of Public Health/Center for Communication Programs, 2018). Oral contraceptives need to be taken daily. The failure rates during the actual use of oral injectables may be due to inconsistent use. Contraceptive failure can occur due to typical use (if couples used contraceptives inconsistently or incorrectly) or perfect use (if couples used contraceptives exactly according to guidance of contraceptive use) (Sundaram $e t$ $a l .$, 2017). Failure to adhere to the daily taking of oral contraceptives may contribute to the risk of unintended pregnancy.

Side effects/health issues were identified in this survey as the most common reason for discontinuation of injectables and oral contraceptives. Based on the IDHS 2017, about $15 \%$ of women aged $15-29$ years and $11 \%$ of women aged 30-49 years did not use any contraceptive methods and did not intend to use contraception in the future due to side effects or health concerns of contraception (National Population and Family Planning Board et al., 2018). There are some side effects or health problems with oral contraceptives and injectables (as the current method of contraception) reported in the IDHS 2017 such as weight gain, headache, nausea, no menstruation, and irregular period (National Population and Family Planning Board et al., 2018). However, this study had no information on the detailed side effects and health problems in each episode among women who discontinued oral contraceptives and injectables.

This study emphasized the importance of comprehensive information regarding contraceptive side effects or health concerns before women start using any contraceptive methods. Comprehensive counseling may improve contraceptive continuation when women understand the possibility of contraceptive side effects or health concerns, particularly if the side effect is transient. Furthermore, women who discontinue their methods due to side effects or health concerns also need to identify an effective backup contraceptive method to remain protected from unintended pregnancy.

Combined reasons for side effects and health concerns account for about thirty-seven percent of discontinuation of injectables and oral contraceptives. Higher pregnancy rates following discontinuation among oral contraceptive users may relate partly to different rates of residual ovarian suppression between the two types of contraceptives following discontinuation of contraceptive methods (Hassan and Killick, 2004).

Consistent with other studies, the postcontraceptive use discontinuation pregnancy rates in both types of contraceptives decline with age. Fertility among women decreased gradually with increasing women's age due to the decline of the quality and quantity of oocytes (Crawford and Steiner, 2015; Rothman et al., 2013; The American College of Obstetricians and Gynecologists Committee on Gynecologic Practice and The Practice Committee of the American Society for Reproductive Medicine, 2014; Vollenhoven and Hunt, 2018). Women's fecundity starts to decline at age 32 years, then decline more quickly at the age of 37 years. The pregnancy rates among women aged more than 35 years are lower compared with those women aged younger than 31 and women aged 31-35 years (The American College of Obstetricians and Gynecologists Committee on Gynecologic Practice and The Practice Committee of the American Society for Reproductive Medicine, 2014). Another study shows a similar result. 
With increased age at the time of marriage, the percentage of women who remain childless increased steadily (Crawford and Steiner, 2015). A prospective study among women aged 20-40 years in Denmark revealed that among parous women, the peak of fecundability was approximately 29-30 years. Among nulliparous women, it was about 27-28 years (Rothman et $a l .$, 2013). In addition, fecundability declines with the increase of women's age. The decline of fecundability is greater among nulliparous women (Rothman et al., 2013). In a study by Cronin et al., the pregnancy rate among women older than 35 years after stopping oral contraceptive use was lower than among younger women. The impact of oral contraceptives and injectables on further fecundity may be stronger among older women, obese women, or women with oligomenorrhea (Hassan and Killick, 2004). Younger women are more fertile than older women, hence in this study pregnancy rates among adolescents were higher compared to older women, especially in those 35 years or older; therefore, adolescent women should be determined as potential targets for contraceptive counseling since they still have a longer reproductive span.

The effects of parity on pregnancy rates after discontinuing contraceptives due to side effects have fluctuated. Since quitting injectables or oral contraceptives, women who have three or more children are more likely to experience unplanned pregnancy due to side effects and/or health issues. This study is consistent with another finding that parous women with three or more children have already "proven" their fertility at least three times, while nulliparous women have not. This means there is a possibility some nulliparous women are infertile, which can reduce pregnancy rates among nulliparous women (Cronin et al., 2009).

Improving family planning services and access is critical, especially for vulnerable women. Lack of ability to plan a pregnancy after stopping contraception due to side effects and/or health concerns has put women at high risk of unintended pregnancy. Women who discontinue their contraceptives due to experiencing side effects may indicate that counseling needs to be improved, especially on the topics of side effects and health concerns. Previous studies have shown that family planning counseling is important to encourage increased modern contraceptive use and minimize contraceptive discontinuation (Damhof et al., 2019; Dehingia et al., 2019; Zapata et al., 2015). Side effects and health concerns after contraceptive use need to be communicated more clearly and comprehensively. Comprehensive counseling can also improve contraceptive continuation and conscientiousness and adherence to shortacting contraceptives. Health providers need to focus on women's needs for suitable contraceptives, especially for women who stop their contraceptives but do not wish to be pregnant. The family planning programs in Indonesia need to provide better management of the side effects of contraceptives.

The results of this study have some limitations. First, subjects in this study were restricted to only reproductive-age women who stopped injectables or oral contraceptives due to side effects and/or health concerns in the 5 years before the interview; therefore, only women with similar criteria should be generalized from the general population in Indonesia for unintended pregnancy rates. Second, the IDHS relied on self-reported information from survey data that may be subject to errors such as recall bias. However, the findings of some associated factors would not be distorted unless there is a significant memory differential among factors being examined. Moreover, the cross-sectional design in this study could not examine the causal relationship.

\section{CONCLUSIONS AND SUGGESTIONS}

\section{Conclusion}

In conclusion, discontinuation of shortacting contraception due to side effects and/or health concerns has put women at high risk of unintended pregnancy. The pregnancy rate post-discontinuation of contraceptive use due to side effects and/or health concerns within 12 months was $17 \%$ for oral contraception users and $16 \%$ for injectable users. Rates of unintended pregnancy following contraceptive discontinuation due to side effects/health concerns were influenced by contraceptive methods, women's age, the number of children they had previously given birth to, prior duration of 
injectables/oral contraceptive used, and occupation.

\section{Suggestion}

Counseling services need to be strengthened by improving provider knowledge and skills to communicate more comprehensively regarding contraceptives' side effects.

\section{REFERENCES}

Ali, M. M., Cleland, J. G., Shah, I. H., and World Health Organization. (2012). Causes and Consequences of Contraceptive Discontinuation: Evidence from 60 Demographic and Health Surveys. In World Health Organization.

Crawford, N. M., and Steiner, A. Z. (2015). Age-Related Infertility. Obstetrics and Gynecology Clinics of North America, 42(1), 15-25.

Cronin, M., Schellschmidt, I., and Dinger, J. (2009). Rate of Pregnancy after using Drospirenone and Other ProgestinContaining Oral Contraceptives. Obstetrics and Gynecology, 114(3), 616-622.

Curtis, S., Evens, E., and Sambisa, W. (2011). Contraceptive Discontinuation and Unintended Pregnancy: An Imperfect Relationship. International Perspectives on Sexual and Reproductive Health, 37(2), 58-66.

Damhof, M. A., Pierik, E., Krens, L. L., Vermeer, M., van Det, M. J., and van Roon, E. N. (2019). Assessment of Contraceptive Counseling and Contraceptive Use in Women After Bariatric Surgery. Obesity Surgery, 29(12), 4029-4035.

Dehingia, N., Dixit, A., Averbach, S., Choudhry, V., Dey, A., Chandurkar, D., Nanda, P., Silverman, J. G., and Raj, A. (2019). Family Planning Counseling and Its Associations with Modern Contraceptive Use, Initiation, and Continuation in Rural Uttar Pradesh, India. Reproductive Health, 16(1), 1-11.

Giorgio, M. M., Utomo, B., Soeharno, N., Aryanty, R. I., Besral, Stillman, M., Philbin, J., Singh, S., and Sedgh, G. (2020). Estimating the Incidence of
Induced Abortion in Java, Indonesia, 2018. International Perspectives on Sexual and Reproductive Health, 46, 211-222.

Habte, D., Teklu, S., Melese, T., and Magafu, M. G. M. D. (2013). Correlates of Unintended Pregnancy in Ethiopia: Results from A National Survey. PLoS ONE, 8(12), 1-8.

Hassan, M. A. M., and Killick, S. R. (2004). Is Previous Use of Hormonal Contraception Associated with A Detrimental Effect on Subsequent Fecundity?. Human Reproduction, 19(2), 344-351.

Hussain, R., and Finer, L. B. (2013). Unintended pregnancy and Unsafe Abortion in the Philippines: Context and Consequences. Issues in Brief (Alan Guttmacher Institute), 3, $1-8$.

Jain, A. K., and Winfrey, W. (2017). Contribution of Contraceptive Discontinuation to Unintended Births in 36 Developing Countries. Studies in Family Planning, 48(3), 269-278.

National Population and Family Planning Board, Statistics Indonesia, Indonesian Ministry of Health, and ICF. (2018). Indonesia Demographic and Health Survey 2017.

Polis, C. B., Bradley, S. E. K., Bankole, A., Onda, T., Croft, T., and Singh, S. (2016). Contraceptive Failure Rates in the Developing World: An Analysis of Demographic and Health Survey Data in 43 Countries.

Rothman, K. J., Wise, L. A., Sørensen, H. T., Riis, A. H., Mikkelsen, E. M., and Hatch, E. E. (2013). Volitional Determinants and Age-related Decline in Fecundability: A General Population Prospective Cohort Study in Denmark. Bone, 99(7), 1958-1964.

Sedgh, G., and Ball, H. (2008). Abortion in Indonesia. In brief (Issue 2).

Singh, A., Singh, A., and Thapa, S. (2015). Adverse Consequences of Unintended Pregnancy for Maternal and Child Health in Nepal. Asia-Pacific Journal of Public Health, 27(2), NP1481NP1491.

Singh, S., Darroch, J. E., and Ashford, L. S. 
(2014). Adding It Up: Costs and Benefits of Investing Sexual and Reproductive Health 2014.

Sundaram, A., Vaughan, B., Kost, K., Bankole, A., Finer, L., Singh, S., and Trussell, J. (2017). Contraceptive Failure in the United States: Estimates from the 2006-2010 National Survey of Family Growth. Perspectives on Sexual and Reproductive Health, 49(1), 7-16.

The American College of Obstetricians and Gynecologists Committee on Gynecologic Practice, and The Practice Committee of the American Society for Reproductive Medicine. (2014). Female age-related fertility decline. Fertility and Sterility, 101(3), 633-634.

USAID. (2018). DHS Contraceptive Calendar Tutorial: The Demographic and Health Survey Program.

Vollenhoven, B., and Hunt, S. (2018). Ovarian Aging and the Impact On Female Fertility. F1000Research, 7.

World Health Organization. (2012). Safe abortion: Technical and Policy Guidance for Health Systems. In World Health Organization (Second ed). WHO Press.

World Health Organization. (2016). Selected Practice Recommendation for Contraceptive Use (Third edition). Department of Reproductive Health and Research.

World Health Organization, and John Hopkins Bloomberg School of Public Health/Center for Communication Programs. (2018). Family Planning: A Global Handbook for Providers (2018 update) (Updated 3r). CCP and WHO Press.

Zapata, L. B., Murtaza, S., Whiteman, M. K., Jamieson, D. J., Robbins, C. L., Marchbanks, P. A., D’Angelo, D. V., and Curtis, K. M. (2015). Contraceptive Counseling and Postpartum Contraceptive Use. American Journal of Obstetrics and Gynecology, 212(2), 171.e1-171.e8. 